
Environmental Effects

\title{
Experimental study of the effect of carbonated brine on wettability and oil displacement for EOR application in the Brazilian Pre-Salt reservoirs
}

\author{
Santiago Drexler, Thais M. G. Silveira, Gabriel De Belli \& Paulo Couto
}

To cite this article: Santiago Drexler, Thais M. G. Silveira, Gabriel De Belli \& Paulo Couto (2019): Experimental study of the effect of carbonated brine on wettability and oil displacement for EOR application in the Brazilian Pre-Salt reservoirs, Energy Sources, Part A: Recovery, Utilization, and Environmental Effects, DOI: 10.1080/15567036.2019.1604877

To link to this article: https://doi.org/10.1080/15567036.2019.1604877

\section{曲 Published online: 15 Apr 2019.}

\section{Submit your article to this journal 주}

Џ Article views: 62

View Crossmark data ¿ 


\title{
Experimental study of the effect of carbonated brine on wettability and oil displacement for EOR application in the Brazilian Pre-Salt reservoirs
}

\author{
Santiago Drexler, Thais M. G. Silveira, Gabriel De Belli, and Paulo Couto \\ LRAP/COPPE, Universidade Federal do Rio de Janeiro, Rio de Janeiro, Brazil
}

\begin{abstract}
Brazilian Pre-Salt carbonate reservoirs are natural candidates for Enhanced Oil Recovery combined with Carbon Capture and Storage due to their high $\mathrm{CO}_{2}$ production. However, the effect of $\mathrm{CO}_{2}$ on rock wettability still needs to be investigated to build representative reservoir models to predict the ultimate oil recovery. This work applied contact angle measurements to study the consequences of carbonated brine on the initial wettability. Moreover, coreflooding experiments were carried out to evaluate the incremental oil recovery obtained by carbonated brine injection. Finally, nonreactive tracer tests and micro computed tomography were used to observe the effects of mineral dissolution on the sweeping efficiency. Carbonated brine induced a decreased oil-wet behavior caused by rock dissolution and desorption of organic compounds resulting in a contact angle reduction of $55^{\circ}$ for the Pre-Salt rock. This contributed to obtain a $27 \%$ increase in oil recovery. Moreover, tracer tests and micro computed tomography verified the formation of preferential flow paths by mineral dissolution. The increased oil production and decreased contact angle encourage further studies on the injection of carbonated brine for the PreSalt scenario.
\end{abstract}

\section{ARTICLE HISTORY}

Received 15 November 2018

Revised 26 February 2019

Accepted 24 March 2019

\section{KEYWORDS}

Enhanced Oil Recovery (EOR); Carbon Capture and Storage (CCS); wettability alteration; contact angle; Pre-Salt reservoirs; $\mathrm{CO}_{2}$ flooding; carbonate dissolution

\section{Introduction}

$\mathrm{CO}_{2}$ is a greenhouse effect gas. Concern about the emissions of this gas has been raised worldwide for the obvious environmental reasons. While several works (Anderson, Hawkins, and Jones 2016; Lee et al. 2013; Specht, Redemann, and Lorenz 2016) link global warming to anthropogenic $\mathrm{CO}_{2}$ emissions, others propose causes such as solar and volcanic activity may have a major contribution (de Larminat 2016; Jian-Bin et al. 2012). In either case, the reduction of $\mathrm{CO}_{2}$ emissions has gained strength in research across the world.

Several methods to remove $\mathrm{CO}_{2}$ from gas streams have been studied. Reviews of papers analyzed by type of technology, year and region were published in the last years (Abu-Khader 2006; Yan 2015; Yan and Zhang 2019). Methods are commonly classified according to whether $\mathrm{CO}_{2}$ removal occurs prior to or after the combustion of fossil fuels. Pre-combustion methods can be hydrate-based (J. Zheng, Zhang, and Linga 2017; Z. Li et al. 2017; Z.-M. Xia et al. 2016; Yang et al. 2014; Z. Xia et al. 2017) or by gasification cycles via syngas (Cormos and Cormos 2019; Siefert, Chang, and Litster 2014; Minchener 2014; Zhu, Shi, and Cai 2016; F. Zhang et al. 2015; Y. Zheng et al. 2014). Post-combustion methods include adsorption in porous materials such as metal-organic frameworks (H. Liu et al. 2014; J.-R. Li, Sculley, and Zhou 2012); absorption in amine solutions (Lepaumier et al. 2010; Z. Zhang et al. 2014b; Z., 2014a; Nakai et al. 2016), amino acid salt solutions (Zhang et al. 2018b) or nanofluids (Z. Zhang 
et al. 2018a) and the use of membranes (Dalane et al. 2017; George et al. 2016; Rezakazemi, Heydari, and Zhang 2017; Wang et al. 2017). After $\mathrm{CO}_{2}$ separation, Carbon Capture and Storage (CCS) consists in the injection and storage of this gas to reduce the emissions. Up to $90 \%$ reduction of direct $\mathrm{CO}_{2}$ emissions from the power stations by CCS was reported (Balat, Balat, and Öz 2009).

$\mathrm{CO}_{2}$ flooding is a well-known Enhanced Oil Recovery (EOR) technique that has been applied for years. A review of worldwide $\mathrm{CO}_{2}$ flooding field projects acknowledged incremental recoveries ranging from 5 to 20\% OOIP (Sheng 2013). Some of the well-known effects that enhance oil recovery are viscosity reduction and oil swelling (Mungan 1981). Moreover, wettability alteration and mineral dissolution can contribute to oil displacement. The main factors for shifting carbonate rock wettability towards water-wet are the reduced $\mathrm{pH}$ of carbonated brines (Fjelde and Asen 2010; Ruidiaz, Winter, and Trevisan 2018; Seyyedi, Sohrabi, and Farzaneh 2015) and the ion exchange induced by low salinity brines (Karimi et al. 2016; Shariatpanahi et al. 2016; Strand, Høgnesen, and Austad 2006).

Considering the need to both increase the oil recovery and decrease the emission of greenhouse gases, $\mathrm{CO}_{2}$ flooding is as an attractive EOR method that can be combined to CCS. Ferguson et al. presented the advantages of CCS application with EOR in the US (Ferguson et al. 2009). They reported that up to 48 billion barrels of oil are recoverable through this technology with an increase of up to $50 \mathrm{GW}$ in power from plants assisted with CCS.

As offshore locations contain giant fields, they are of interest for the application of EOR/CCS. Sweatman et al. proposed that these fields present a more viable scenario than onshore fields in highly populated areas (Sweatman, Crookshank, and Edman 2011). They also reported several cases of success of offshore implementation at the North Sea and Gulf of Mexico.

The Brazilian carbonate Pre-Salt fields, which are among the greatest oil discoveries of the last decades, are natural offshore candidates for the application of EOR/CCS. Lula Field in Santos Basin contains 8.3 billion barrels of oil equivalent reserves (Formigli, Pinto, and Almeida 2009) with $28^{\circ}$ API oil, high salinity (23\%) brine and gas to oil ratios (GOR) of up to $27 \mathrm{scf} / \mathrm{stb}$ with $\mathrm{CO}_{2}$ concentration up to 12\% (Pepin et al. 2014; Pizarro, De Santanna, and Branco 2012). The main features for the application of CCS in Lula Pre-Salt field were presented elsewhere (de Almeida et al. 2010).

However, $\mathrm{CO}_{2}$ injection causes dramatic changes in the fluid-fluid and rock fluid interactions. This unique environment represents a challenge in terms of wettability assessment: carbonates tend to have variable wettability adding uncertainties in models that represent fluid flow in the porous medium (Ahmed Elfeel et al. 2013; Wilson 2014). In addition, another concern is that mineral dissolution and precipitation from $\mathrm{CO}_{2}$-brine-rock interactions could affect porosity and permeability of reservoir and caprock. A recent study showed that long-term $\mathrm{CO}_{2}$ injection could enhance or compromise sand caprock sealing efficiency depending on the dissolution/precipitation ratio of different minerals (Liu, Xiaofei, and Zhuo 2018).

While there papers describing Pre-Salt rocks in the literature (Teles et al. 2016), there is no detailed data describing their wettability and the effect of $\mathrm{CO}_{2}$ on the rock-fluid interactions. A recent study (Ruidiaz, Winter, and Trevisan 2018) considered the wettability alteration of dolomite and limestone cores and its effects on oil recovery using de-waxed and de-asphaltened Pre-Salt crude and formation and injection brines (200,000 and 35,000 ppm salinities respectively) using the Amott-Harvey Index and spontaneous imbibition tests. The authors found that switching the brine salinity and injecting carbonated brine had a dramatic effect on the wettability of the dolomitic cores towards water-wet increasing oil recovery. These wettability trends may differ when crudes containing asphaltenes and waxes are considered.

At this initial stage of research, reliable experimental data is of paramount importance to improve the description of the reservoir behavior. This work aims to contribute to fill the gap in experimental results regarding the effects of $\mathrm{CO}_{2}$ injection in the Pre-Salt environment. We propose the use of contact angle for initial wettability evaluation, coreflood experiments and non-reactive tracer tests combined with X-ray micro computed tomography (micro-CT) to analyze the advantages and drawbacks of $\mathrm{CO}_{2}$ flooding in terms of EOR. Finally, we suggest the next experimental steps for the acquisition of data to develop a reliable reservoir model. 


\section{Materials and experimental methods}

\section{Materials}

Synthetic formation brine (Brine D) and desulphated seawater (DSW) were prepared by dissolving the required concentration of the different salts (i.e. $\mathrm{NaCl}, \mathrm{KCl}, \mathrm{MgCl}_{2}, \mathrm{CaCl}_{2}, \mathrm{BaCl}_{2}, \mathrm{SrCl}_{2}, \mathrm{LiCl}$, $\mathrm{Na}_{2} \mathrm{SO}_{4}, \mathrm{NaBr}, \mathrm{CH}_{3} \mathrm{COONa}$ and $\mathrm{NaHCO}_{3}$ from Sigma Aldrich USA, purity over 99\%) in deionized water (conductivity lower than $1 \mu \mathrm{S} / \mathrm{cm}$ ). The DSW composition used in this work corresponded to seawater except that the $\mathrm{Na}_{2} \mathrm{SO}_{4}$ was excluded in this brine to avoid sulfate precipitation inside the cores (Egermann, Bazin, and Vizika 2005). The ion concentrations, $\mathrm{pH}$ and density of the brines used are in Table 1. Carbonated desulphated seawater (CSW) and $\mathrm{CO}_{2}$ saturated oil were prepared by injecting the required amount of $\mathrm{CO}_{2}$ (Praxair Brasil, 99.9\% purity) in piston cells containing the degassed dead fluid. $\mathrm{CO}_{2}$ solubility and $\mathrm{pH}$ of carbonated brines were calculated using OLI Studio, and $\mathrm{CO}_{2}$ solubility of oil was calculated using PVTSim (Calsep) and the data from gas chromatography (Agilent 7890, data not showed). The resulting $\mathrm{pH}$ of carbonated Brine D and DSW were 2.89 and 3.45, respectively.

Pre-Salt dead crude oil (Oil D) was supplied by Shell Brasil. SARA analysis was performed by IP 143 $n$-heptane precipitation method (asphaltenes) and medium pressure liquid chromatography (saturates, resins and aromatics). In addition, the total acid and basic numbers (TAN and TBN) were obtained by the procedure in ASTM D664, and API was measured in a Mettler Toledo DM40 densitometer. Viscosity was measured using ASTM D7042. These properties are summed up in Table 2.

Calcite and dolomite minerals were purchased at Wards Science, and Indiana Limestone (IL) samples were supplied by Koçurek Industries. Pre-Salt reservoir D rock samples were also provided by Shell Brasil. Calcite and dolomite were characterized by thin layer microscopic petrography. For the more complex rocks, X-ray diffraction (XRD) was performed for mineralogy analysis, and the results are in Table 3. IL samples consist basically of calcite with traces of quartz. In contrast, Pre-Salt rock have high contents of dolomite, followed by calcite and quartz. Nevertheless, no precise $\mathrm{Ca} / \mathrm{Mg}$ ratio on the rock surface should be inferred because dolomite with $\mathrm{Ca} / \mathrm{Mg}$ greater than 1 is included in the dolomitic fraction.

\section{Contact angle}

Before measuring the Contact Angle, the rock sample needs to be cleaned, cut to corresponding slab sizes $(25.4 \times 25.4 \mathrm{~mm}$ and $3 \mathrm{~mm}$ thickness $)$ and polished to minimize roughness. Then, it needs to be aged to allow the surface interactions with the fluids. For this, the slabs were placed in closed recipient

Table 1. Ionic composition, total dissolved solids (TDS), $\mathrm{pH}, \mathrm{CO}_{2}$ solubility and density ( $\rho$ ) of the brines used in this work.

\begin{tabular}{|c|c|c|}
\hline Ion & Brine D & DSW \\
\hline $\mathrm{Na}^{+}$ & 62,250 & 12,000 \\
\hline $\mathrm{Ca}^{2+}$ & 17,480 & 500 \\
\hline $\mathrm{Mg}^{2+}$ & 1,430 & 1,700 \\
\hline $\mathrm{K}^{+}$ & 5,180 & 500 \\
\hline $\mathrm{Ba}^{2+}$ & 149 & - \\
\hline $\mathrm{Sr}^{2+}$ & 1,800 & 9 \\
\hline $\mathrm{Li}^{+}$ & 152 & - \\
\hline $\mathrm{SO}_{4}^{2+}$ & 15 & - \\
\hline $\mathrm{Cl}^{-}$ & 121,400 & 21,347 \\
\hline $\mathrm{HCO}_{3}^{-}$ & 1,094 & 101 \\
\hline Acetate & 188 & - \\
\hline $\mathrm{Br}^{-}$ & 586 & - \\
\hline TDS (ppm) & 200,319 & 35,177 \\
\hline $\mathrm{pH}$ at $25^{\circ} \mathrm{C}$ & 6.1 & 8.6 \\
\hline $\mathrm{CO}_{2}$ solubility at $60^{\circ} \mathrm{C}$ and $1000 \mathrm{psi}(\mathrm{mol} \%)$ & 0.83 & 1.35 \\
\hline$\rho(\mathrm{g} / \mathrm{ml})$ at $25^{\circ} \mathrm{C}$ and $14.7 \mathrm{psi}$ & 1.11 & 1.03 \\
\hline
\end{tabular}


Table 2. SARA analysis, acid and basic numbers (TAN, TBN), API, viscosity and $\mathrm{CO}_{2}$ solubility of Oil D.

\begin{tabular}{lc}
\hline & Oil D \\
\hline Saturates & 56.65 \\
Aromatics & 30.11 \\
Resins & 10.95 \\
Asphaltenes & 2.29 \\
TAN (mg KOH/g) & 0.40 \\
TBN (mg KOH/g) & 4.0 \\
API $\left(^{\circ}\right)$ & 23.36 \\
Viscosity $(\mathrm{cP})$ at $60^{\circ} \mathrm{C}$ and $14.7 \mathrm{psi}$ & 27.4 \\
$\mathrm{CO}_{2}$ solubility at $60^{\circ} \mathrm{C}$ and $1000 \mathrm{psi}(\mathrm{mol} \%)$ & 47.5 \\
\hline
\end{tabular}

Table 3. XRD composition of the rock samples in wt\%.

\begin{tabular}{lcccc}
\hline & Quartz & K-Feldspar & Calcite & Dolomite/Ca-Dolomite \\
\hline Indiana Limestone & 0.7 & - & 99.3 & - \\
Pre-Salt D rock & 6.5 & 0.9 & 32.4 & 60.2 \\
\hline
\end{tabular}

with the respective fluid and kept at constant reservoir (test) temperature. Initially, the slabs were aged in brine for 1 day and then in crude oil for 30 days. After that, the excess bulk oil on the rock surface was removed by centrifugation at $3,000 \mathrm{rpm}$ for 20 minutes following the procedure in the literature (Seyyedi, Sohrabi, and Farzaneh 2015).

CA measurements were carried out using a Drop Shape Analyzer DSA 100E supplied by Kruss with a HPHT chamber designed by Eurotechnica. It consists of a goniometer with a high-resolution camera and sapphire glass windows capable of resisting temperatures up to $150^{\circ} \mathrm{C}$ and pressures up to 7,500 psi. All wetted parts are made of Hastelloy, making it appropriate for contact with high salinity brines and high concentrations of $\mathrm{CO}_{2}$. The fluids to be used in the test are pumped from their respective piston cells at controlled rate. In all experiments crude oil was used as the drop phase and brine as the environment phase. A capillary tube of $1.6 \mathrm{~mm}$ external diameter is used for forming the oil droplets, which are injected from the bottom. The equipment has a PID temperature controller and a thermocouple that measures the internal fluid temperature with a resolution of $0.1^{\circ} \mathrm{C}$. The pressure transducers have a resolution of $\pm 0.25 \%$.

All tests were performed at $60^{\circ} \mathrm{C}$ and 1,000 psi. In the tests containing no $\mathrm{CO}_{2}$, the aged rock slab was placed in the measuring cell. Then, brine was injected until reaching the desired pressure, and the temperature was raised. Finally, a drop of oil was injected and images of the drop on the rock surface were acquired every 30 seconds for 24 hours.

In the tests containing $\mathrm{CO}_{2}$ pre-saturated fluids, the corresponding volume of $\mathrm{CO}_{2}$ to achieve saturation is injected into the separate piston cells containing the brine and oil phases. The recombined fluids with $\mathrm{CO}_{2}$ are shaken in the piston cell and let to reach mass transfer equilibrium for at least $24 \mathrm{~h}$. After that, the rock slab is placed in the chamber, and test brine with no dissolved $\mathrm{CO}_{2}$ is injected to eliminate the air in the equipment and lines as in the previous procedures. Then, the system is pressurized, and the temperature is increased until reaching the test conditions. The pre-equilibrated brine with dissolved $\mathrm{CO}_{2}$ is then injected at a low flowrate (i.e. $50 \mathrm{~cm}^{3} / \mathrm{h}$ ) at the top of the chamber while the brine with no dissolved $\mathrm{CO}_{2}$ is retracted on the bottom keeping the test pressure constant. This exchange of fluids is continued until the total volume injected is greater than twice the volume of the system (including the dead volume of the lines). Finally, the pre-saturated oil with dissolved $\mathrm{CO}_{2}$ is injected to form the drop.

Each experiment was repeated three times, and equilibrium left and right CAs were measured towards the denser phase (brine). Values lower than $70^{\circ}$ represent brine-wet substrates, values higher than $110^{\circ}$ indicate oil-wet rocks and the rocks with CA between 70 and $110^{\circ}$ are intermediate-wet. The informed result is the average of all measured values, and the error bars represent the standard error of the mean. 


\section{Rock slab characterization}

Rock surfaces were observed in a Zeiss Stereo Discovery V8 optical microscope. In addition, confocal microscopy for qualitative characterization of surface topography was performed in Zeiss Laser Scanning Microscope LSM 700 using an individual area of $1.2 \times 1.2 \mathrm{~mm}$ and a tile scan of $6.5 \times 5.1 \mathrm{~mm}$ and a depth ranging between 300 and $700 \mu \mathrm{m}$. Characterization by Scanning electron microscopy (SEM) was performed in a Hitachi TM3030 Plus under low vacuum atmosphere and an acceleration voltage of $1.5 \mathrm{kV}$.

Macroscopic roughness measurements were performed in a Bruker Dektak XT profilometer following the recommendations in ASME B46.1-1995. For each sample, six measurements at different parts of the surface were performed. Each measurement scanned an extension of $1 \mathrm{~cm}$ in 60 seconds. The range was set to $6.5 \mu \mathrm{m}$ with a radius of $12.5 \mu \mathrm{m}$, a force of $3 \mathrm{mg}$ and a resolution of $0.555 \mu \mathrm{m}$. Finally, mineralogical composition of rock samples was characterized by X-ray diffraction XRD (Bruker D8 Advanced diffractometer).

\section{Experimental core analysis}

Since identifying the pore structure of a rock is crucial for the characterization of flow in porous media, we carried out the conventional core analysis (pore-volume, porosity and absolute permeability), a nonreactive tracer test and, a CT scan, before and after the special core analysis (SCAL) to investigate the effects of carbonated brine injection on the core. In this study, the SCAL consists in core floods at reservoir conditions aiming to compare the performances of seawater and carbonated seawater injections.

Prior to commencing any coreflood experiment, an Indiana limestone (IL) sample with dimensions of $20 \mathrm{~cm}$ length and $3.79 \mathrm{~cm}$ diameter was prepared: the core was cleaned, dried and vacuumed. The non-aged core was water-wet, as verified by CA measurements (data not shown). The physical properties and the results from the conventional core analysis before the SCAL is presented in the results section (3.2). The porosity was measured using helium pore volume technique. The average absolute permeability was calculated as a base permeability to nitrogen and synthetic brine.

\section{Tracer tests}

In this work, a non-adsorbing chemical tracer test was performed aiming to investigate the heterogeneities of the sample in terms of changes in reservoir connectivity and breakthrough time. Sodium iodide (NaI reagent grade, Sigma-Aldrich) was used to prepare the brine used at the single phase tracer test performed before and after the core flooding tests with DSW and carbonated seawater (EOR). The IL core sample was saturated with normal brine $\left(0.2 \mathrm{wt} \% \mathrm{NaCl}\right.$ and $0.8 \mathrm{wt} \% \mathrm{CaCl}_{2}$ ). A step-input tracer test was performed by injecting $10 \mathrm{wt} \% \mathrm{NaI}$ in normal brine. Slugs of 2 pore volumes of tracer were injected, followed by 2 to 3 pore volumes of brine at constant flow rate of $50 \mathrm{~cm}^{3} / \mathrm{h}$. The analytical method used to identify sodium iodide in normal brine was gravimetry, so effluents were collected and analyzed in a Mettler Toledo DM40 density meter. Finally, tracer concentrations versus injected pore volumes were plotted.

\section{SCAL}

The SCAL consisted in two core flood experiments performed at high pressure and high temperature: desulphated seawater injection (DSW) as secondary oil recovery and carbonated desulphated seawater injection (CSW) as tertiary oil recovery or EOR. After the conventional core analysis and the tracer test, synthetic formation brine $\mathrm{D}$ was injected to fully saturate the core $(\mathrm{Sw}=100 \%)$ and measure absolute permeability. Thereafter, a series of mineral oils and kerosene followed by Pre-Salt Oil D were injected to establish the irreducible water saturation $(S w i=24 \%)$. At this point, the aging process was started. The temperature of the coreflood rig was increased $20^{\circ} \mathrm{C}$ per day until reaching $60^{\circ} \mathrm{C}$. Back pressure was kept constant at 1,000 psi. Oil D was injected at $0.5 \mathrm{~cm}^{3} / \mathrm{h}$ during the 30 days aging. 
After the aging, DSW was injected at a rate of $5 \mathrm{~cm}^{3} / \mathrm{h}$ at test conditions $\left(60^{\circ} \mathrm{C}\right.$ and $\left.1,000 \mathrm{psi}\right)$. The pressure drop and volume of oil recovered were recorded. The injection was carried out until a $99 \%$ water cut was achieved. Due to the small dimensions of the core, a bump flood $\left(50 \mathrm{~cm}^{3} / \mathrm{h}\right)$ was performed as a best practice to recover the oil that was trapped due to capillary end effects. Once the pressure drop was constant and there was no more significant oil production, the injection pump was stopped. Then DSW injection was switched to CSW injection as tertiary oil recovery and the procedure was repeated. For this second injection, two bump floods $\left(50\right.$ and $100 \mathrm{~cm}^{3} / \mathrm{h}$ ) were performed to check incremental oil recovery from the limestone core.

\section{micro-CT scan analysis}

For further investigation on the nature of the internal pore structure and identification of wormholes in the rock after the coreflooding experiments, a micro-CT scan imaging was carried out on the IL core. The equipment used was a GE v $\mid$ Tome $\mid x$ X-ray micro-CT scanner. The scan was performed throughout the $20 \mathrm{~cm}$ length of the sample at $150 \mathrm{keV}$ and $700 \mu \mathrm{A}$, resulting in a volume with resolution of $76 \mu \mathrm{m}$ voxel size. The X-rays were filtered through a $0.1 \mathrm{~mm}$ copper plate. The software Fiji/ImageJ and Avizo 9.5 were used for digital reconstruction of the sample's pore system. The complete procedure for $3 \mathrm{D}$ image reconstruction including the segmentation of the images and selection of the threshold value was previously presented elsewhere (Silva et al. 2018).

\section{Results and discussion}

\section{Contact angle}

Contact angle (CA) measurements were run for calcite, dolomite, limestone and Pre-Salt reservoir $\mathrm{D}$ rock. The objective of these tests is to assess the effects of $\mathrm{CO}_{2}$ on the initial wettability of the PreSalt rock. The other rocks and minerals were considered to compare analogue behavior between different carbonates. Dolomite, calcite and quartz are the most abundant minerals in the Pre-Salt rock considered in this work. Limestone is a sedimentary rock mainly composed by calcite with fairly homogeneous properties. Figure 1 shows the results, and Figure 2 contains images of several drops used to calculate the CA values.

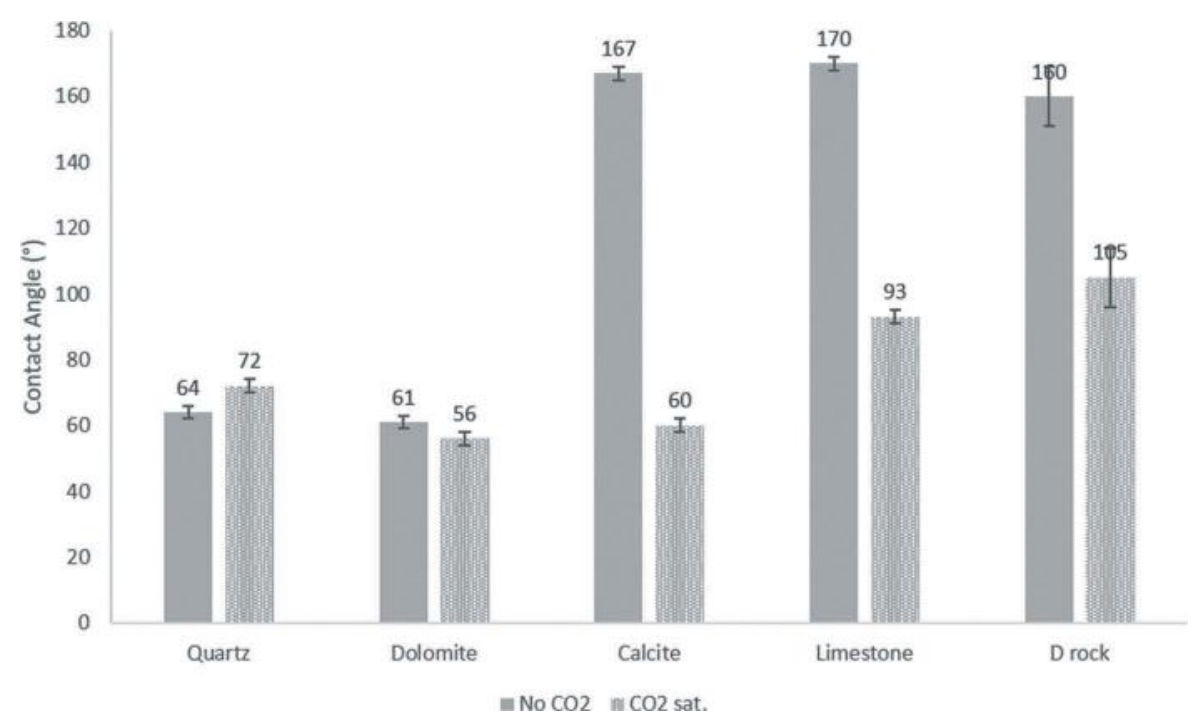

Figure 1. Contact angle measurements for quartz, dolomite, calcite, limestone outcrops and Field D rock using dead (no $\left.\mathrm{CO}_{2}\right)$ and carbonated formation brine (D). Aging: 1 day in brine, 30 days in oil. Conditions: $60^{\circ} \mathrm{C}$ and 1000 psi. 


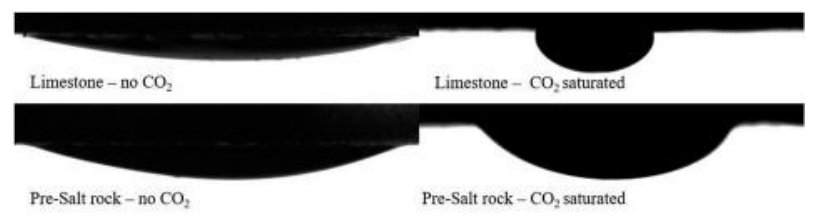

Figure 2. Image showing drops for contact angle measurements for limestone outcrops and Field D rock using Formation Brine and Oil D. Aging: 1 day in brine, 30 days in oil. Conditions: $60^{\circ} \mathrm{C}$ and 1,000 psi.

The results illustrated in Figure 1 show clear trends. Quartz remains water-wet suggesting that, even with a low TAN/TBN ratio, the interactions of the basic compounds with the acidic surface of quartz are not strong enough to shift the wettability towards oil-wet. In contrast, after 30 days aging all carbonate rocks with exception of dolomite mineral are strongly oil-wet. This indicates that wettability alteration mechanisms such as electrostatic interaction of negatively-charged asphaltenes and acid groups in the oil with the positively-charged basic surface take place during aging. It is interesting to remark that the initial wettability of the Pre-Salt rock showed a similar behavior to that of calcite and limestone. Although the main component of this rock's bulk composition is dolomite, wettability is dictated by the surface composition. For this complex rock, wettability may be governed by the presence of other components resulting in stronger oil-rock interactions. Previous works using different oils and brines also found oil-wet behavior for dolomitic cores (Mahani et al. 2017, 2015). Further investigation is required to specify the characteristic of this rock controlling its wettability.

The differentiated behavior of dolomite mineral may be caused by its weak interaction with basic and acid compounds in crude Oil D. Previous researchers (Morrow, Cram, and McCaffery 1973) found similar contact angle values on both quartz and dolomite mineral surfaces using water and a series of oils containing sulfur and nitrogen compounds as fluids. They also reported that acid compounds could shift wettability of the mineral, but since the interactions were not strong enough, wettability would readily reverse towards water-wet. Nevertheless, since the oils and brines used by the authors differ to those in this work, it is not possible to affirm that the wettability is a result of the same rock-fluid interactions at this time. Another cause for the lower contact angles obtained for dolomite could be that, since $\mathrm{Mg}^{2+}$ is ten time less reactive with acid groups than $\mathrm{Ca}^{2+}$ due to its reduced ionic size and hydration energy (Shariatpanahi et al. 2016), the interactions between the crude and the mineral are not strong enough to disrupt the water film during the aging process.

Figures 1 and 2 show that for the experiments with $\mathrm{CO}_{2}$ saturated brine, the wettability of all carbonate rocks is shifted towards water-wet as reported in other experimental works (Farzaneh, Seyyedsar, and Sohrabi 2016; Ruidiaz, Winter, and Trevisan 2018). Several factors have been proposed as contributing to this shift in wettability. The most critical factor seems to be the mineral dissolution by brine acidification (summarized in reaction 1 below), which was fully described elsewhere (Plummer, Wigley, and Parkhurst 1978; Seyyedi, Sohrabi, and Farzaneh 2015; Svensson and Dreybrodt 1992).

$$
\mathrm{CaCO}_{3}(\mathrm{~s})+\mathrm{H}_{2} \mathrm{O}(\mathrm{l})+\mathrm{CO}_{2}(\mathrm{aq}) \rightarrow \mathrm{Ca}^{2+}(\mathrm{aq})+2 \mathrm{HCO}_{3}{ }^{-}(\mathrm{aq})
$$

$\mathrm{CO}_{2}$ dissolution shifts the $\mathrm{pH}$ of Brine $\mathrm{D}$ from 6.11 to 2.89 at the specific test conditions of this work. As mineral dissolution takes place, the adsorbed layer of oil during the aging process is removed from the rock surface. This reverses the wettability to more water-wet, which corresponds to that of the unaged rock. This effect was previously reported for $\mathrm{CO}_{2}$ flooding in a core from a dolomitic formation (Potter 1987).

The effects of $\mathrm{CO}_{2}$ on wettability are more critical for calcite which is more reactive by acid attack (Svensson and Dreybrodt 1992). For the more heterogeneous rocks, a wettability shift is still noticeable. Nevertheless, both limestone and Pre-Salt rock are in the intermediate-wet after contact with carbonated brine.

Oppositely to carbonate rocks, quartz showed a slight increase in contact angle. Seyyedi et al. explained this effect due to the decreased negative charge on quartz's surface as $\mathrm{CO}_{2}$ is dissolved in the brine, reducing its repulsion with the negatively-charged species in the oil. 
The effect of carbonated brine on Pre-Salt rock surface was assessed using different microscopy techniques. First, images were acquired in an optical microscope (Figure 3) evidencing increased roughness. This was confirmed by measuring the macroscopic surface roughness in a profilometer. An increase of $24 \%$ in average surface roughness (from 2207 to $2740 \mathrm{~nm}$ ) was observed supporting the microscope observations. In addition, confocal microscopy analysis was carried out on the same slabs to support this discussion. Figure 4 shows an increase in heterogeneity of the surface topography caused by the interaction between carbonated brine and the reservoir rock.

The same rocks were analyzed by scanning electron microscopy (SEM). The images are shown in Figure 5. The rock surface after contact with carbonated brine shows visible signs of acid attack, such as abrasion effects and alteration of rhombohedral structures of calcite and dolomite. In addition, scale precipitation after mineral dissolution is likely due to the appearance of small salt crystals on top of the rock's matrix.

The results discussed in this section indicate that carbonated water injection reduces the strongly oil-wet behavior of the carbonate rocks considered in this work. This effect impacts on the relative permeability curves (Potter 1987) favoring the displacement of oil.

The next step was to evaluate the effects of $\mathrm{CO}_{2}$ on wettability when injection water (DSW) is employed. For this, tests at the same conditions as the previously discussed were run for calcite and limestone using DSW instead of Brine D (Figure 6). It can be observed that DSW with no dissolved $\mathrm{CO}_{2}$ did not alter wettability of the limestone significantly which remained oil-wet. For the calcite slab, a decrease in the CA was found; nevertheless, this effect was not sufficient to change the initial wettability of the mineral.

CSW had a similar impact on wettability than carbonated formation brine. A dramatic decrease in the CA was found for both rocks shifting wettability to more water-wet. These results encourage the application of carbonated under Pre-Salt conditions.

\section{Experimental core analysis}

The effect of $\mathrm{CO}_{2}$ on the performance of water floods was investigated in terms of oil recovery and differential pressure. In this study, an Indiana limestone (IL) core sample was flooded with DSW (secondary recovery). Then, it went through tertiary recovery (EOR) by CSW injection. Both experiments were performed at 1,000 psi and $60^{\circ} \mathrm{C}$. In Figure 7 , the oil recovery curve of DSW injection through IL core is presented. The water injection began when saturation of oil was $76 \%$ (connate water saturation of 24\%). During the period from the start of water injection until water

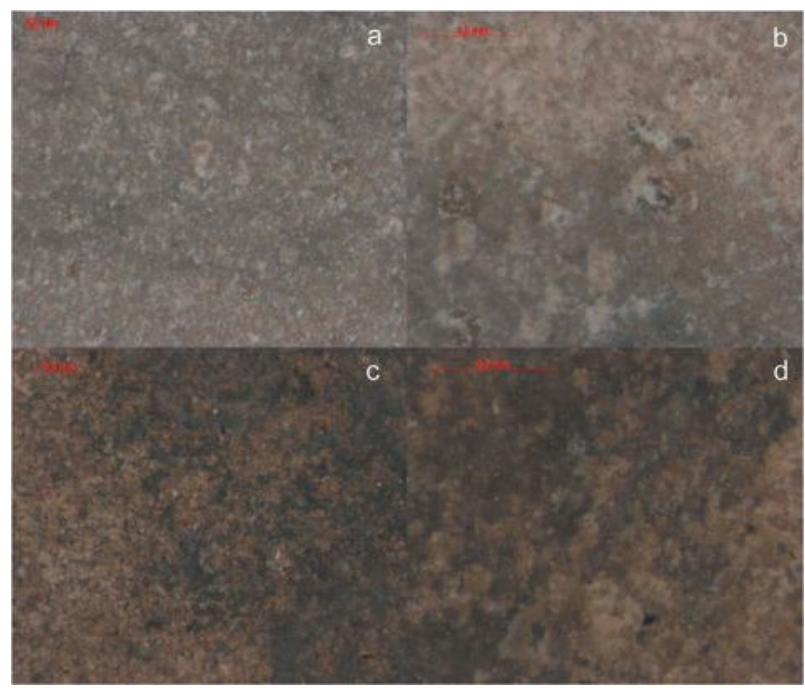

Figure 3. Optical microscope images of a Pre-Salt Field D rock sample. Figures (a) and (b) new sample with different magnification levels. Figures (c) and (d) samples after test with $\mathrm{CO}_{2}$-saturated brine with different magnification levels. 


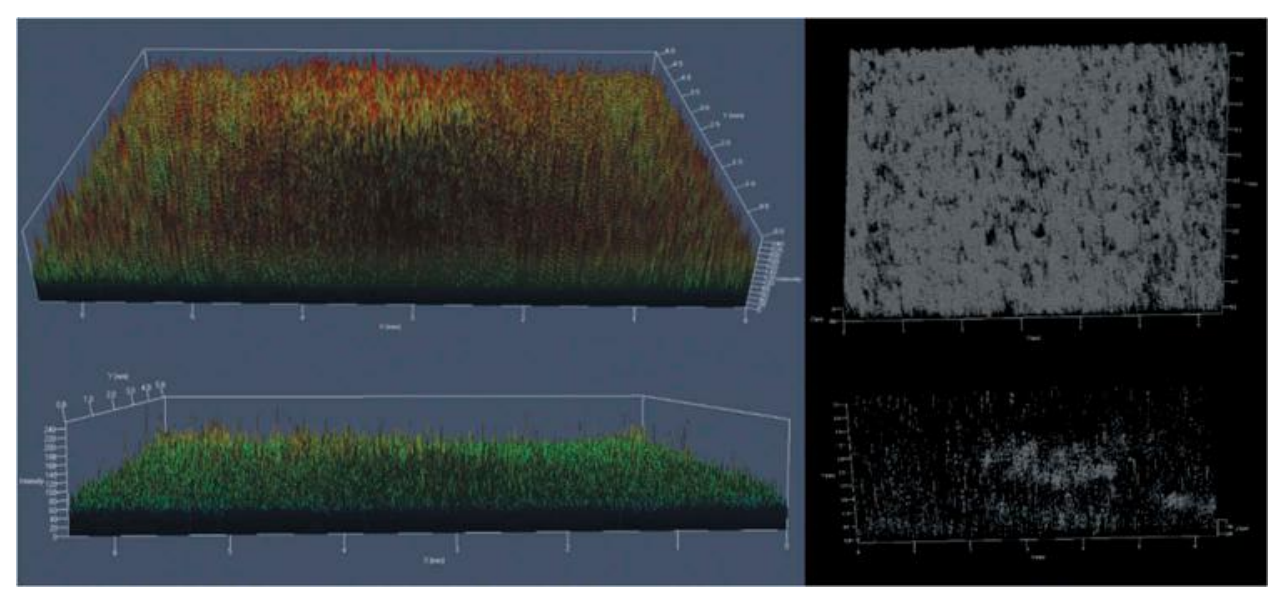

Figure 4. Confocal microscopy showing surface topography of Pre-Salt Field D rock. Top: new sample. Bottom: sample after test with $\mathrm{CO}_{2}$-saturated brine.
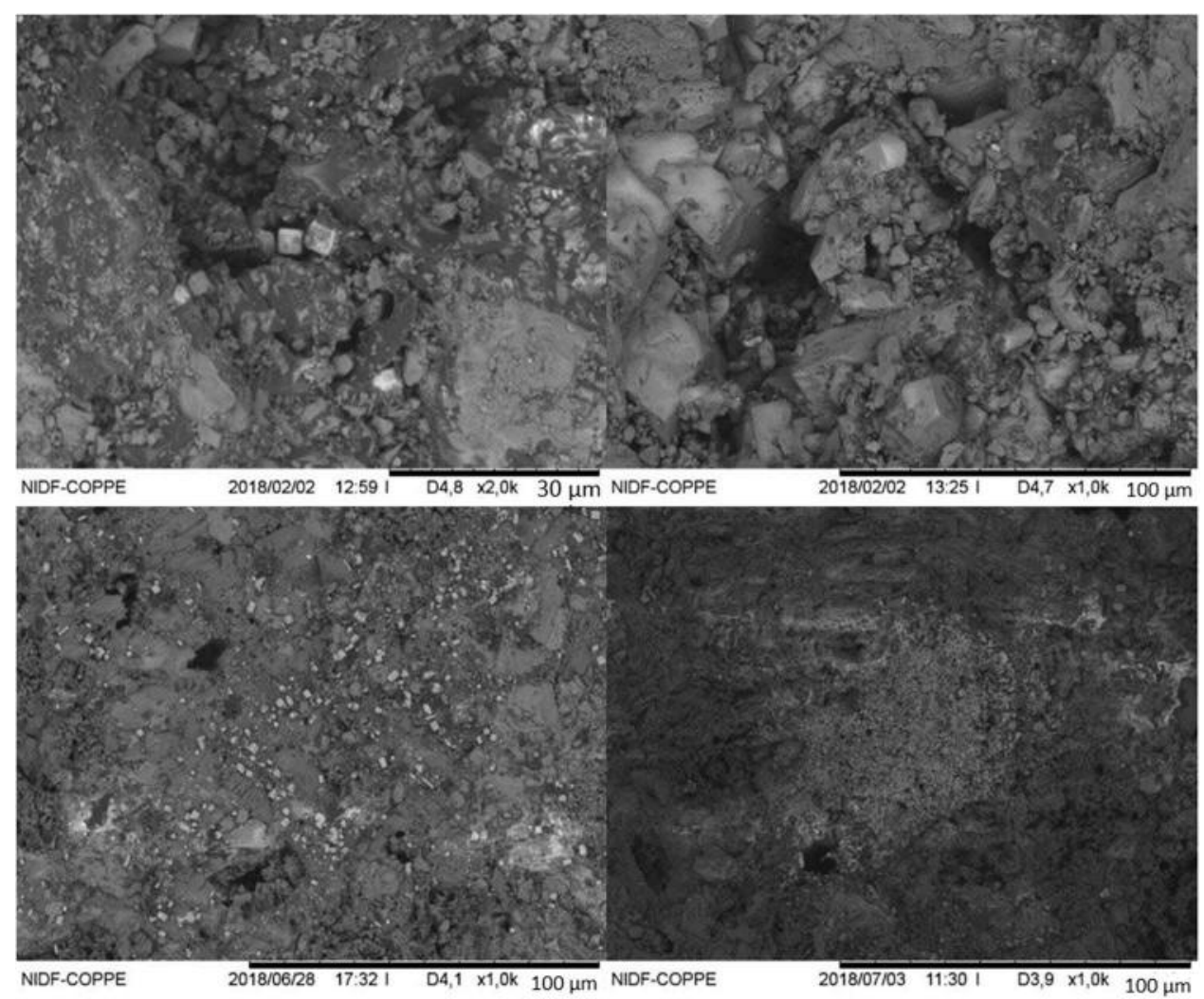

Figure 5. SEM images of Pre-Salt Field D sample. Top: new sample. Bottom: sample after test with $\mathrm{CO}_{2}$-saturated brine.

breakthrough (BT), only oil was being produced at the core outlet at constant rate by an immiscible oil/water sweeping front. Correspondingly, the differential pressure increased as water saturation increased inside the core. After the water BT (0.2 PV), oil recovery decreased dramatically, as 


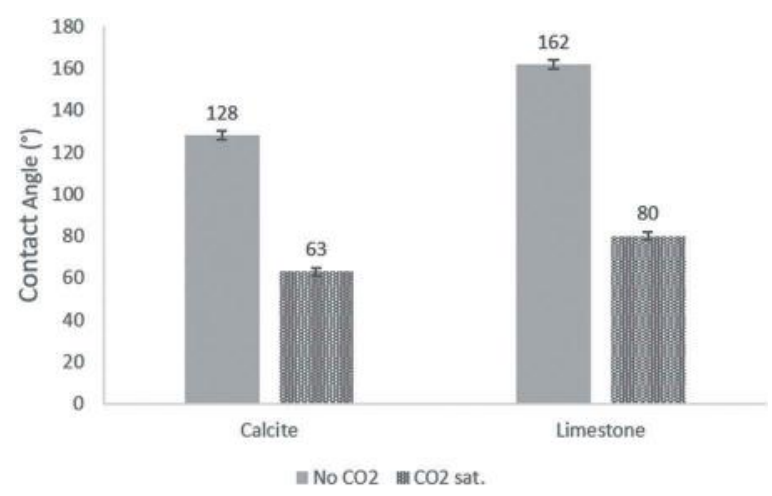

Figure 6. Contact angle measurements for calcite and limestone outcrops using dead (no $\mathrm{CO}_{2}$ ) and carbonated injection brine (DSW). Aging: 1 day in brine, 30 days in oil. Conditions: $60^{\circ} \mathrm{C}$ and 1,000 psi.

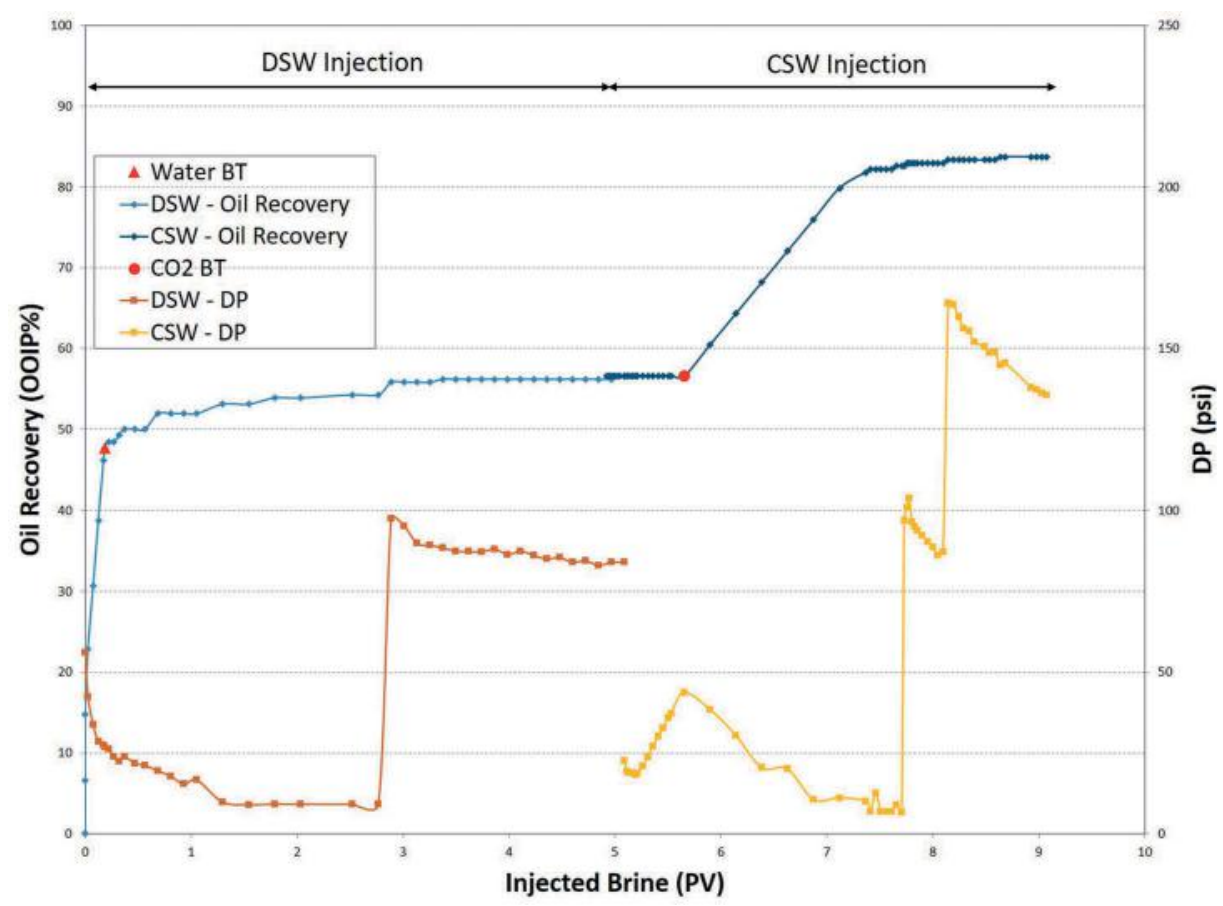

Figure 7. Coreflood results of secondary injection of DSW and tertiary injection of CSW for IL core sample.

evidenced by the plateau in Figure 7. After injection of 5 PV of DSW and considering the bump flood, the overall recovery factor was close to $56 \%$ of OOIP (oil initially in place).

To investigate the efficiency of the EOR process, the corresponding oil recoveries and pressure drop over the core were analyzed against the injected pore volumes of DSW and CSW, as showed in Figure 7. Initially, only brine was being produced at the core outlet until reaching $\mathrm{CO}_{2} \mathrm{BT}$ (5.6 PV), at which oil was produced along with gas and water until the end of the injection period. After injection of $4 \mathrm{PV}$, the incremental oil recovery was $27 \%$ of OOIP. Therefore, oil recovery was enhanced by the carbonated seawater injection reaching an ultimate recovery of $83 \%$ OOIP. The extra oil recovery can be explained mainly by wettability alteration and rock dissolution as observed in the contact angle measurements, added to other effects of $\mathrm{CO}_{2}$ flooding such us oil swelling and viscosity reduction. 
After SCAL experiments, the IL core was cleaned and routine core analysis was performed again to compare the results achieved before and after the coreflooding tests. In this case, routine core analysis is important to report and investigate dissolution or deposition of sediments in the pore structure. Table 4 shows that dry weight and absolute permeability decreased after the CSW injection. That can be explained by the reaction of the carbonate rock with carbonated brine in agreement with previous discussions.

\section{Tracer tests}

Figure 8 shows tracer concentration profiles of Indiana limestone core sample before and after the coreflooding tests (SCAL). The goal of the tracer tests was to confirm the existence of a preferential flow path created by carbonate rock dissolution. Observing the plot, it is possible to affirm that, for this sample, the profile was more symmetric before than after the CSW injection. This indicates that, after carbonated brine injection, the sample was less homogenous in terms of sweeping efficiency.

After the coreflood experiment with carbonated brine, the sample presented an earlier breakthrough followed by a longer tail, which is related to the presence of blocked pore volume. This behavior was expected since the carbonated water dissolved pore walls and plugged small paths, therefore creating preferential paths and dead-end pores in agreement to the scaling and dissolution observations from the SEM images. The dominant flow path is also indicated by higher slope of the concentration curve compared to the slower response from the sample before the carbonated seawater injection.

\section{micro-CT scan analysis}

High-resolution images of the pores and grains were used to digitally reconstruct the sample and visualize the porous media. After the X-ray micro-CT scan, it was possible to identify a dominant path created by the dissolution of the rock after carbonate seawater injection as EOR technique. The visualization of macro and micro wormholes is dependent on the resolution of the micro-CT images. Due to the dimensions of the core sample used in this work, only the macro flow path was identified through CT images with resolution of $76 \mu \mathrm{m}$ voxel size. Figure 9 shows the 3D rock reconstruction. Observing the image, it is possible to affirm that in the first quarter length of the sample, a wormhole was created by the dissolution of the rock matrix creating a preferential flow path that significantly alters the flow behavior (Grigg and Svec 2008) corroborating the results from the chemical tracer test.

Table 4. Conventional core analysis data before and after SCAL (DSW and CSW injections).

\begin{tabular}{lcccccc}
\hline Sample id & Dry weight $(\mathrm{g})$ & Length $(\mathrm{cm})$ & Diameter $(\mathrm{cm})$ & Pore volume $(\mathrm{cc})$ & Porosity $(\%)$ & Abs. permeability $(\mathrm{mD})$ \\
\hline IL & 510.18 & 20 & 3.79 & 34.04 & 15.06 & 5.40 \\
IL after SCAL & 509.11 & 20 & 3.79 & 31.46 & 13.91 & 3.98 \\
\hline
\end{tabular}

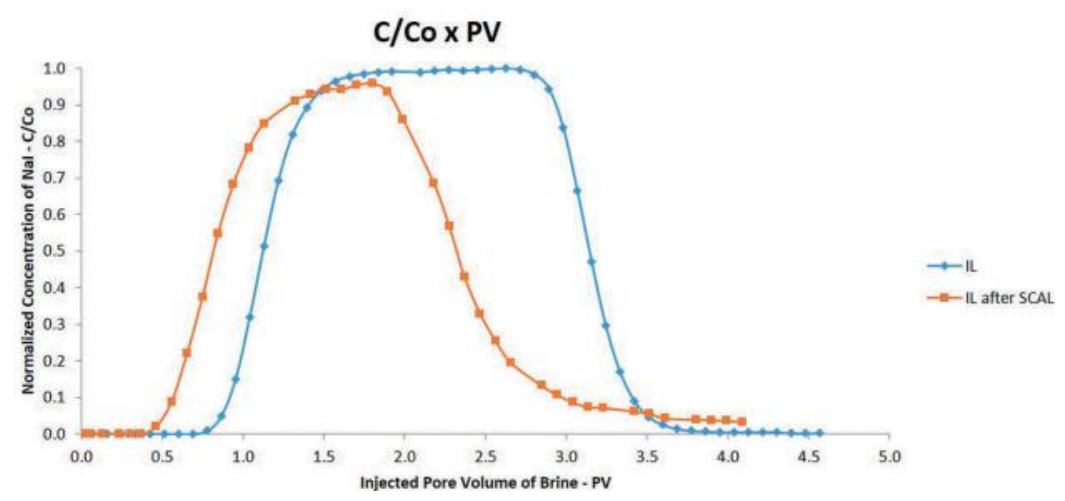

Figure 8. Normalized concentration of chemical tracer versus injected pore volume of brine before after the SCAL analysis (CSW and DSW injections). 


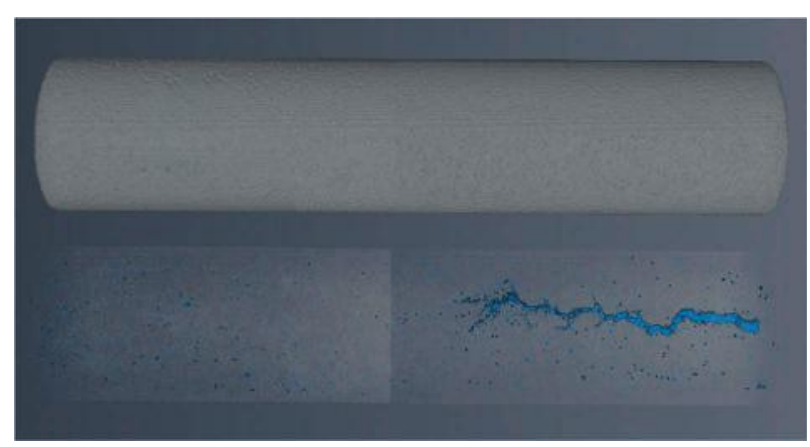

Figure 9. 3D reconstruction of Indiana limestone after carbonated seawater flood and the preferential path created by the rock dissolution.

\section{Conclusions}

This experimental work is an initial contribution to the ongoing research studying the effects of carbonated brine injection regarding EOR/CCS application in Brazilian Pre-Salt carbonate reservoirs. The conclusions and remarks for future studies are summed up below:

(1) Aged Pre-Salt rock showed an initial oil-wet behavior analogue to that of limestone outcrops.

(2) The injection of carbonated brine shifted initial wettability towards neutral or water-wet. This is caused by rock reactivity with acid environment and desorption of organic molecules adsorbed during the aging process.

(3) This change was more pronounced for calcite mineral, which is more reactive with carbonated brine.

(4) The injection of carbonated brine resulted in an incremental $27 \%$ recovery, reaching $83 \%$ OOIP ultimate recovery in coreflooding experiments. Wettability alteration aids in the production of residual oil.

(5) Rock dissolution was evident in contact angle and coreflooding experiments. This should be addressed in more detail in future studies as it could impact negatively on the sweeping efficiency by the creation of preferential paths and reduction of absolute permeability.

\section{Ackowledgement}

This research was carried out in association with the ongoing R\&D project registered as ANP19027-2, "Desenvolvimento de infraestrutura para pesquisa e desenvolvimento em recuperação avançada de óleo - EOR no Brasil” (UFRJ/Shell Brasil/ANP) - setting-up an advanced EOR Lab facility for R\&D in Brasil, sponsored by Shell Brasil under the ANP R\&D levy as "Compromisso de Investimentos com Pesquisa e Desenvolvimento".

\section{Funding}

This work was supported by the Shell Brasil Ltda [ANP19027-2];

\section{References}

Abu-Khader, M. M. 2006. Recent progress in $\mathrm{CO}_{2}$ capture/sequestration: a review. Energy Sources, Part A: Recovery, Utilization, and Environmental Effects 28 (14):1261-79. doi:10.1080/009083190933825.

Ahmed Elfeel, M., A. Al-Dhahli, S. Geiger, and M. I. J. van Dijke. 2013. "Multi-scale simulation of WAG flooding in naturally fractured reservoirs." EAGE Annual Conference \& Exhibition Incorporating SPE Europec. London, UK: Society of Petroleum Engineers. doi:10.2118/164837-MS.

de Almeida, A. S. D., S. D. T. C. Lima, P. S. Rocha, A. M. T. D. Andrade, C. C. M. Branco, and A. C. C. Pinto. 2010. "CCGS opportunities in the santos basin pre-salt development." In SPE International Conference on Health, Safety 
and Environment in Oil and Gas Exploration and Production 2010, 2:840-49. Rio de Janeiro, Brazil: Society of Petroleum Engineers. doi:10.2118/126566-MS.

Anderson, T. R., E. Hawkins, and P. D. Jones. 2016. $\mathrm{CO}_{2}$, the greenhouse effect and global warming: from the pioneering work of arrhenius and callendar to today's earth system models. Endeavour 40 (3):178-87. doi:10.1016/j. endeavour.2016.07.002.

Balat, M., H. Balat, and C. Öz. 2009. Applications of carbon dioxide capture and storage technologies in reducing emissions from fossil-fired power plants. Energy Sources, Part A: Recovery, Utilization, and Environmental Effects 31 (16):1473-86. doi:10.1080/15567030802093138.

Cormos, A.-M., and C.-C. Cormos. 2019. Techno-economic assessment of combined hydrogen \& power co-generation with carbon capture: the case of coal gasification. Applied Thermal Engineering 147(January):29-39. Pergamon. doi:10.1016/J.APPLTHERMALENG.2018.10.064.

Dalane, K., Z. Dai, G. Mogseth, M. Hillestad, and L. Deng. 2017. Potential applications of membrane separation for subsea natural gas processing: a review. Journal of Natural Gas Science and Engineering 39(March):101-17. Elsevier. doi:10.1016/J.JNGSE.2017.01.023.

de Larminat, P. 2016. Earth climate identification vs. anthropic global warming attribution. Annual Reviews in Control 42(January):114-25. Pergamon. doi:10.1016/J.ARCONTROL.2016.09.018.

Egermann, P., B. Bazin, and O. Vizika. 2005. “An experimental investigation of reaction-transport phenomena during $\mathrm{CO}_{2}$ injection." SPE Middle East Oil and Gas Show and Conference. Kingdom of Bahrain: Society of Petroleum Engineers. doi:10.2118/93674-MS.

Farzaneh, S. A., S. M. Seyyedsar, and M. Sohrabi. 2016. "Enhanced heavy oil recovery by liquid $\mathrm{Co}_{2}$ injection under different injection strategies." SPE Annual Technical Conference and Exhibition,Dubai, UAE. doi:10.2118/181635-MS.

Ferguson, R. C., C. Nichols, T. Van Leeuwen, and V. A. Kuuskraa. 2009. Storing $\mathrm{CO}_{2}$ with enhanced oil recovery. Energy Procedia 1(1):1989-96. Elsevier. doi:10.1016/j.egypro.2009.01.259.

Fjelde, I., and S. M. Asen. 2010. "Wettability alteration during water flooding and carbon dioxide flooding of reservoir chalk rocks." In SPE EUROPEC/EAGE Annual Conference and Exhibition. Barcelona, Spain: Society of Petroleum Engineers. doi:10.2118/130992-MS.

Formigli, J. M., A. C. C. Pinto, and A. S. Almeida. 2009. "SS: santos basin's pre-salt reservoirs development: the way ahead." In Offshore Technology Conference. Houston, Texas: Offshore Technology Conference. doi:10.4043/19953-MS.

George, G., N. Bhoria, S. AlHallaq, A. Abdala, and V. Mittal. 2016. Polymer membranes for acid gas removal from natural gas. Separation and Purification Technology 158(January):333-56. Elsevier. doi:10.1016/J.SEPPUR.2015.12.033.

Grigg, R. B., and R. Svec. 2008. "Injectivity changes and $\mathrm{CO}_{2}$ retention for EOR and sequestration projects." $S P E$ Symposium on Improved Oil Recovery. Tulsa, OK, USA: Society of Petroleum Engineers. doi:10.2118/110760-MS.

Jian-Bin, H., W. Shao-Wu, L. Yong, Z. Zong-Ci, and W. Xin-Yu. 2012. Debates on the causes of global warming. Advances in Climate Change Research 3(1):38-44. Elsevier. doi:10.3724/SP.J.1248.2012.00038.

Karimi, M., R. S. Al-Maamari, S. Ayatollahi, and N. Mehranbod. 2016. Wettability alteration and oil recovery by spontaneous imbibition of low salinity brine into carbonates: impact of $\mathrm{Mg}^{2+}, \mathrm{SO}_{4}{ }^{2-}$ and cationic surfactant. Journal of Petroleum Science and Engineering 147:560-69. Elsevier. doi:10.1016/j.petrol.2016.09.015.

Lee, Z. H., S. Sethupathi, K. T. Lee, S. Bhatia, and A. R. Mohamed. 2013. An overview on global warming in southeast asia: $\mathrm{CO}_{2}$ emission status, efforts done, and barriers. Renewable and Sustainable Energy Reviews 28 (December):71-81. Pergamon. doi:10.1016/J.RSER.2013.07.055.

Lepaumier, H., S. Martin, D. Picq, B. Delfort, and P.-L. Carrette. 2010. New amines for $\mathrm{CO}_{2}$ capture. III. Effect of alkyl chain length between amine functions on polyamines degradation. Industrial \& Engineering Chemistry Research 49 (10):4553-60. American Chemical Society. doi:10.1021/ie902006a.

Li, J.-R., J. Sculley, and H.-C. Zhou. 2012. Metal-organic frameworks for separations. Chemical Reviews 112 (2):869-932. United States. doi:10.1021/cr200190s.

Li, Z., D.-L. Zhong, L. Yi-Yu, J. Yan, and Z.-L. Zou. 2017. Preferential enclathration of $\mathrm{CO}_{2}$ into tetra-N-butyl phosphonium bromide semiclathrate hydrate in moderate operating conditions: application for $\mathrm{CO}_{2}$ capture from shale gas. Applied Energy 199(August):370-81. Elsevier. doi:10.1016/J.APENERGY.2017.05.043.

Liu, B., F. Xiaofei, and L. Zhuo. 2018. Impacts of $\mathrm{CO}_{2}$-brine-rock interaction on sealing efficiency of sand caprock: a case study of shihezi formation in ordos basin. Advances in Geo-Energy Research 2 (4):380-92. doi:10.26804/ ager.2018.04.03.

Liu, Huang, Bei Liu, Li-Chiang Lin, Guangjin Chen, Yuqing Wu, Jin Wang, Xueteng Gao 2014. A hybrid absorption-adsorption method to efficiently capture carbon. Nature Communications 5(October):5147. Nature Pub. Group. doi:10.1038/ncomms6147.

Mahani, H., A. L. Keya, S. Berg, and R. Nasralla. 2015. "The effect of salinity, rock type and pH on the electrokinetics of carbonate-brine interface and surface complexation modeling." SPE Reservoir Characterisation and Simulation Conference and Exhibition. Abu Dhabi, UAE: Society of Petroleum Engineers. doi:10.2118/175568-MS.

Mahani, H. R., M. S. Berg, A. Fadili, R. Nasralla, D. Voskov, and V. Joekar-Niasar. 2017. Insights into the impact of temperature on the wettability alteration by low salinity in carbonate rocks. Energy and Fuels 31 (8):7839-53. doi:10.1021/acs.energyfuels.7b00776. 
Minchener, A. J. 2014. Gasification based CCS challenges and opportunities for China. Fuel 116(January):904-09. Elsevier. doi:10.1016/J.FUEL.2013.02.046.

Morrow, N. R., P. J. Cram, and F. G. McCaffery. 1973. Displacement studies in dolomite with wettability control by octanoic acid. Society of Petroleum Engineers Journal 13 (4):221-32. doi:10.2118/3993-PA.

Mungan, N. 1981. Carbon dioxide flooding-fundamentals. Journal of Canadian Petroleum Technology $20(1): 7$. Petroleum Society of Canada. doi:10.2118/81-01-03.

Nakai, H., Y. Nishimura, T. Kaiho, T. Kubota, and H. Sato. 2016. Contrasting mechanisms for $\mathrm{CO}_{2}$ absorption and regeneration processes in aqueous amine solutions: insights from density-functional tight-binding molecular dynamics simulations. Chemical Physics Letters 647:127-31. doi:10.1016/j.cplett.2016.01.059.

Pepin, A., N. Bize-Forest, S. J. Montoya Padilla, C. Abad, P. Schlicht, and A. de Castro Machado. 2014. "Pre-salt carbonate reservoir analog selection for stimulation optimization." In International Petroleum Technology Conference. Kuala Lumpur, Malaysia.

Pizarro, J., O. De Santanna, and C. C. M. Branco. 2012. "Challenges in implementing an EOR project in the pre-salt province in deep offshore Brasil." SPE EOR Conference at Oil and Gas West Asia. Muscat, Oman: Society of Petroleum Engineers. doi:10.2118/155665-MS.

Plummer, L. N., T. M. L. Wigley, and D. L. Parkhurst. 1978. The kinetics of calcite dissolution in $\mathrm{CO}_{2}$-water systems at 5 degrees to 60 degrees $\mathrm{C}$ and 0.0 to 1.0 Atm $\mathrm{CO}_{2}$. American Journal of Science 278 (2):179-216. doi:10.2475/ ajs.278.2.179.

Potter, G. F. 1987. "The effects of $\mathrm{CO}_{2}$ flooding on wettability of west texas dolomitic formations." SPE Annual Technical Conference and Exhibition. Dallas, TX, USA: Society of Petroleum Engineers. doi:10.2118/16716-MS.

Rezakazemi, M., I. Heydari, and Z. Zhang. 2017. Hybrid systems: combining membrane and absorption technologies leads to more efficient acid gases $\left(\mathrm{CO}_{2}\right.$ and $\left.\mathrm{H} 2 \mathrm{~S}\right)$ removal from natural gas. Journal of CO2 Utilization 18 (March):362-69. Elsevier. doi:10.1016/J.JCOU.2017.02.006.

Ruidiaz, E. M., A. Winter, and O. V. Trevisan. 2018. Oil recovery and wettability alteration in carbonates due to carbonate water injection. Journal of Petroleum Exploration and Production Technology 8(1):249-58. Springer Berlin Heidelberg. doi:10.1007/s13202-017-0345-z.

Seyyedi, M., M. Sohrabi, and A. Farzaneh. 2015. Investigation of rock wettability alteration by carbonated water through contact angle measurements. Energy and Fuels 29 (9):5544-53. doi:10.1021/acs.energyfuels.5b01069.

Shariatpanahi, S. F., P. Hopkins, H. Aksulu, S. Strand, T. Puntervold, and T. Austad. 2016. Water based EOR by wettability alteration in dolomite. Energy and Fuels 30 (1):180-87. doi:10.1021/acs.energyfuels.5b02239.

Sheng, J. 2013. Enhanced oil recovery field case studies. Waltham, MA, USA: Gulf Professional Publishing. https:// books.google.com.br/books?id=oyqRxuf5RskC.

Siefert, N. S., B. Y. Chang, and S. Litster. 2014. Exergy and economic analysis of a cao-looping gasifier for IGFC-CCS and IGCC-CCS. Applied Energy 128(September):230-45. Elsevier. doi:10.1016/J.APENERGY.2014.04.065.

Silva, W., G. D. A. Lopes, E. H. Rios, F. O. Hoerlle, E. M. B. D. Pontedeiro, L. F. B. de Almeida, J. L. D. Alves, and P. Couto. 2018. Representative elementary volume of a region of interest of a heterogeneous carbonate rock using X-ray computed microtomography and numerical simulation. Revista Brasileira de Geofísica 36 (4):1-8. doi:10.22564/rbgf.v36i4.1975.

Specht, E., T. Redemann, and N. Lorenz. 2016. Simplified mathematical model for calculating global warming through anthropogenic $\mathrm{CO}_{2}$. International Journal of Thermal Sciences 102(April):1-8. Elsevier Masson. doi:10.1016/J. IJTHERMALSCI.2015.10.039.

Strand, S., E. J. Høgnesen, and T. Austad. 2006. Wettability alteration of carbonates-Effects of potential determining ions (Ca2+ and SO42-) and temperature. Colloids and Surfaces A: Physicochemical and Engineering Aspects 275 (1-3):1-10. Elsevier. doi:10.1016/J.COLSURFA.2005.10.061.

Svensson, U., and W. Dreybrodt. 1992. Dissolution kinetics of natural calcite minerals in $\mathrm{CO}_{2}$-water systems approaching calcite equilibrium. Chemical Geology 100 (1-2):129-45. doi:10.1016/0009-2541(92)90106-F.

Sweatman, R. E., S. Crookshank, and S. Edman. 2011. "Outlook and technologies for offshore $\mathrm{CO}_{2}$ EOR/CCS projects." Offshore Technology Conference. Houston, Texas, USA: Offshore Technology Conference. doi:10.4043/21984-MS.

Teles, A. P., A. C. Machado, A. Pepin, N. Bize-Forest, R. T. Lopes, and I. Lima. 2016. Analysis of subterranean pre-salt carbonate reservoir by $\mathrm{x}$-ray computed microtomography. Journal of Petroleum Science and Engineering 144 (August):113-20. Elsevier. doi:10.1016/J.PETROL.2016.03.008.

Wang, M., Z. Wang, S. Zhao, J. Wang, and S. Wang. 2017. Recent advances on mixed matrix membranes for CO2 separation. Chinese Journal of Chemical Engineering 25(11):1581-97. Elsevier. doi:10.1016/J.CJCHE.2017.07.006.

Wilson, A. 2014. Multiscale simulation of WAG flooding in naturally fractured reservoirs. Journal of Petroleum Technology 66(1):73-75. Society of Petroleum Engineers. doi:10.2118/0114-0073-JPT.

Xia, Z.-M., L. Xiao-Sen, Z.-Y. Chen, L. Gang, J. Cai, Y. Wang, K.-F. Yan, and X. Chun-Gang. 2017. Hydrate-based acidic gases capture for clean methane with new synergic additives. Applied Energy 207(December):584-93. Elsevier. doi:10.1016/J.APENERGY.2017.06.017.

Xia, Z.-M., L. Xiao-Sen, Z.-Y. Chen, L. Gang, K.-F. Yan, X. Chun-Gang, L. Qiu-Nan, and J. Cai. 2016. Hydrate-based $\mathrm{CO} 2$ capture and $\mathrm{CH} 4$ purification from simulated biogas with synergic additives based on gas solvent. Applied Energy 162(January):1153-59. Elsevier. doi:10.1016/J.APENERGY.2015.02.016. 
Yan, J. 2015. Carbon capture and storage (CCS). Applied Energy 148:A1-6. doi:10.1016/j.apenergy.2015.03.019.

Yan, J., and Z. Zhang. 2019. Carbon capture, utilization and storage (CCUS). Applied Energy 235:1289-99. doi:10.1016/ j.apenergy.2018.11.019.

Yang, M., Y. Song, L. Jiang, Y. Zhao, X. Ruan, Y. Zhang, and S. Wang. 2014. Hydrate-based technology for $\mathrm{CO}_{2}$ capture from fossil fuel power plants. Applied Energy 116(March):26-40. Elsevier. doi:10.1016/J.APENERGY.2013.11.031.

Zhang, F., D. Xu, Y. Wang, M. D. Argyle, and M. Fan. 2015. $\mathrm{CO}_{2}$ gasification of powder river basin coal catalyzed by a cost-effective and environmentally friendly iron catalyst. Applied Energy 145(May):295-305. Elsevier. doi:10.1016/J. APENERGY.2015.01.098.

Zhang, Z., J. Cai, F. Chen, L. Hao, W. Zhang, and Q. Wenjie. 2018a. Progress in enhancement of $\mathrm{CO}_{2}$ absorption by nanofluids: a mini review of mechanisms and current status. Renewable Energy 118(April):527-35. Pergamon. doi:10.1016/J.RENENE.2017.11.031.

Zhang, Z., Y. Yan, Y. Chen, and L. Zhang. 2014a. Investigation of $\mathrm{CO}_{2}$ absorption in methyldiethanolamine and 2-(1-piperazinyl)-ethylamine using hollow fiber membrane contactors: part C. Effect of operating variables. Journal of Natural Gas Science and Engineering 20(September):58-66. Elsevier. doi:10.1016/J.JNGSE.2014.06.008.

Zhang, Z., Y. Yan, L. Zhang, Y. Chen, and J. Shunxiang. 2014b. CFD Investigation of $\mathrm{CO}_{2}$ capture by methyldiethanolamine and 2-(1-piperazinyl)-ethylamine in membranes: Part B. Effect of membrane properties. Journal of Natural Gas Science and Engineering 19(July):311-16. Elsevier. doi:10.1016/J.JNGSE.2014.05.023.

Zhang, Z., L. Yifu, W. Zhang, J. Wang, M. R. Soltanian, and A. G. Olabi. 2018b. Effectiveness of amino acid salt solutions in capturing $\mathrm{CO}_{2}$ : a review. Renewable and Sustainable Energy Reviews 98(September):179-88. Elsevier Ltd. doi:10.1016/j.rser.2018.09.019.

Zheng, J., P. Zhang, and P. Linga. 2017. Semiclathrate hydrate process for pre-combustion capture of $\mathrm{CO}_{2}$ at near ambient temperatures. Applied Energy 194(May):267-78. Elsevier. doi:10.1016/J.APENERGY.2016.10.118.

Zheng, Y., Y. Shi, L. Shuang, Y. Yang, and N. Cai. 2014. Elevated temperature hydrogen/carbon dioxide separation process simulation by integrating elementary reaction model of hydrotalcite adsorbent. International Journal of Hydrogen Energy 39(8):3771-79. Pergamon. doi:10.1016/J.IJHYDENE.2013.12.167.

Zhu, X., Y. Shi, and N. Cai. 2016. Integrated gasification combined cycle with carbon dioxide capture by elevated temperature pressure swing adsorption. Applied Energy 176(August):196-208. Elsevier. doi:10.1016/J.APENERGY.2016.05.068. 